\title{
Impact of ultrafiltration and nanofiltration of an industrial fish protein hydrolysate on its bioactive properties
}

\author{
Laurent Picot ${ }^{1,{ }^{*}}$, Rozenn Ravallec ${ }^{2}$, Martine Fouchereau-Péron ${ }^{3}$, Laurent Vandanjon ${ }^{4,5}$, Pascal \\ Jaouen $^{4}$, Maryse Chaplain-Derouiniot ${ }^{4}$, Fabienne Guérard ${ }^{6}$, Aurélie Chabeaud ${ }^{6}$, Yves LeGal $^{3}$, Oscar \\ Martinez Alvarez ${ }^{3,7}$, Jean-Pascal Bergé ${ }^{8}$, Jean-Marie Piot ${ }^{1}$, Irineu Batista ${ }^{9}$, Carla Pires ${ }^{9}$, Gudjon \\ Thorkelsson ${ }^{10,11}$, Charles Delannoy ${ }^{12}$, Greta Jakobsen $^{13}$, Inez Johansson1 ${ }^{3}$, Patrick Bourseau ${ }^{4,5}$
}

${ }^{1}$ UMR CNRS 6250 LIENSS, Université de La Rochelle, La Rochelle, France

2 ProBioGEM, UPRES EA-1026, IUT A-Polytech'Lille, USTL, Lille, France

${ }^{3}$ UMR BOREA (Biologie des Organismes et Ecosystèmes Aquatiques), MNHN/CNRS 7208/IRD 207/UPMC, Station de Biologie Marine, Concarneau, France

${ }^{4}$ UMR CNRS 6144 GEPEA, Université de Nantes, Saint-Nazaire, France

${ }^{5}$ LIMATB, Université de Bretagne Sud, Lorient, France

${ }^{6}$ ANTiOX, Université de Bretagne Occidentale, Quimper, France

${ }^{7} \mathrm{CSIC}$, Consejo Superior de Investigaciones Científicas, Instituto del Frío, Madrid, Spain

${ }^{8}$ IFREMER, STAM, Nantes, France

9 Ipimar, Lisbon, Portugal

${ }^{10}$ Matis ohf, Reykjavik, Iceland

${ }^{11}$ University of Iceland, Reykjavik, Iceland

${ }^{12}$ Copalis, Boulogne sur Mer, France

${ }^{13}$ Marinova, Højmark, Denmark

*: Corresponding author : L. Picot, email address : laurent.picot@univ-Ir.fr

\begin{abstract}
:
BACKGROUND: Numerous studies have demonstrated that in vitro controlled enzymatic hydrolysis of fish and shellfish proteins leads to bioactive peptides. Ultrafiltration (UF) and/or nanofiltration (NF) can be used to refine hydrolysates and also to fractionate them in order to obtain a peptide population enriched in selected sizes. This study was designed to highlight the impact of controlled UF and NF on the stability of biological activities of an industrial fish protein hydrolysate (FPH) and to understand whether fractionation could improve its content in bioactive peptides.
\end{abstract}

RESULTS: The starting fish protein hydrolysate exhibited a balanced amino acid composition, a reproducible molecular weight (MW) profile, and a low sodium chloride content, allowing the study of its biological activity. Successive fractionation on UF and NF membranes allowed concentration of peptides of selected sizes, without, however, carrying out sharp separations, some MW classes being found in several fractions. Peptides containing Pro, Hyp, Asp and Glu were concentrated in the UF and NF retentates compared to the unfractionated hydrolysate and UF permeate, respectively. Gastrin/cholecystokinin-like peptides were present in the starting FPH, UF and NF fractions, but fractionation did not increase their concentration. In contrast, quantification of calcitonin gene-related peptide (CGRP)-like peptides demonstrated an increase in CGRP-like activities in the UF permeate, relative to the starting FPH. The starting hydrolysate also showed a potent antioxidant and radical 
scavenging activity, and a moderate angiotensin-converting enzyme (ACE)-1 inhibitory activity, which were not increased by UF and NF fractionation.

CONCLUSION: Fractionation of an FPH using membrane separation, with a molecular weight cut-off adapted to the peptide composition, may provide an effective means to concentrate CGRP-like peptides and peptides enriched in selected amino acids. The peptide size distribution observed after UF and NF fractionation demonstrates that it is misleading to characterize the fractions obtained by membrane filtration according to the MW cut-off of the membrane only, as is currently done in the literature. Copyright $\odot 2010$ Society of Chemical Industry

Keywords: Fish protein hydrolysate (FPH), ultrafiltration (UF), nanofiltration (NF), membrane separation, fractionation process, bioactive peptide

\section{INTRODUCTION}

Peptides resulting from natural digestion or controlled enzymatic hydrolysis of food proteins exhibit not only nutritional but also biological activities of dietary or pharmacological interest ${ }^{1,2}$. Following ingestion, proteins are hydrolyzed in the stomach by $\mathrm{HCl}$ and pepsins and, at a lesser extent, in the upper part of the intestine by trypsin and chymotrysin. The resulting enzymatic hydrolysate mostly consists in a mixture of free amino acids and dipeptides, able to bind gastric receptors on mucosal cells, and to be resorbed via a transcellular transport across the intestinal brush border cells, as demonstrated using synthetic oligopeptides ${ }^{3,4}$. Beyond this classical paradigm, it was demonstrated that oligopeptides can also cross the intestinal border following a transepithelial route or oligopeptides transporters ${ }^{5,6}$. Some factors such as the intraluminal hypertonicity increase this process ${ }^{7}$. In vitro and in vivo studies have shown that enzymatic hydrolysis of dietary proteins leads to bioactive peptides such as growth factors ${ }^{8}$, immunomodulators ${ }^{9}$, antimicrobial ${ }^{10}$, antithrombotic ${ }^{11}$, ACE-1 inhibitors ${ }^{12}$, opiates or antiproliferative peptides ${ }^{13}$. Research focused on peptides contained in fish protein hydrolysates (FPH) demonstrated they also constitute promising health benefits molecules for nutritional or pharmaceutical applications ${ }^{14-16}$. Only few studies were performed to confirm the in vivo biological activity of FPH peptides, but convincing data were obtained on relevant animal models, such as spontaneously hypertensive or diabetic rats. For instance, in vitro ${ }^{17-19}$ and in vivo studies on hypertensive rats ${ }^{20-22}$ demonstrated that pollack flesh or tuna muscle peptides inhibit ACE-1 and decrease blood pressure. The in vivo hypotensive activity of a short peptide identified in a sardine muscle hydrolysate was also demonstrated in humans, by a dietary study on mild hypertensive subjects $^{23}$. 
Fish and shellfish peptides could also contribute to free radicals scavenging and pathologies prevention ${ }^{24}$. Peptides obtained from shrimp by-products ${ }^{25}$, hoki frames ${ }^{26}$, tuna backbone proteins ${ }^{27}$, jumbo squid skin gelatine ${ }^{28,29}$, conger eel muscle ${ }^{30}$ and yellow stripe trevally ${ }^{31}$ exert a significant in vitro antioxidant activity. Most antioxidant peptides identified are short (5 to 16 amino acids), contain hydrophobic amino acids, Val and Leu, at the N-terminus and Pro, His or Tyr in their sequence ${ }^{14}$. Tyrosines substantially contribute to the scavenging of free radicals because their phenolic lateral chains act as potent electron donors ${ }^{32,28,29}$, thus allowing the termination of the radical chain reaction ${ }^{31,33}$.

FPH have also been identified as a source of hormonal peptides ${ }^{34-37,41-42}$, particularly peptides able to bind gastrin / cholecystokinins (CCK), and CGRP receptors. FPH peptides also cross-react with specific antibodies directed against these hormones. Gastro-intestinal secretagogue peptides such as Gastrin/CCK ${ }^{34-36}$ exhibit a large spectrum of activities ranging from the stimulation of protein synthesis ${ }^{37}$, the control of intestinal mobility and the secretion of digestive enzymes ${ }^{38}$. Involvement of CCK-8 in the satiety mechanisms controlling food intake in humans is well documented ${ }^{39,40}$, and the gastric localization of gastrin and CCK receptors suggests that dietary peptides acting as agonists on these receptors could be of interest as satietogenic ingredients in functional food. CGRP is a neuropeptide synthesized by alternative splicing of the calcitonin gene ${ }^{41}$ and regulating a large number of physiological functions such as vasodilatation, gastric acid secretion and cardiac metabolism ${ }^{42,43}$. Binding of CGRP to its receptors reduces acidic secretion and the risk of ulceration, suggesting that peptides acting as CGRP receptors agonists could be of pharmacological interest 44,45 .

Several studies refer to the use of UF in order to refine hydrolysates and to increase their specific activity in the perspective of industrial upgrading of by-products to produce bioactive ingredients for human food or animal feeding. The specific activity of UF fractions is then compared with that of the initial hydrolysate, with the aim of identifying the most active fractions. Several hydrolysates from different substrates have been fractionated in this way at the Pukyong National University in Pusan, South Korea: hot washing waters of cod frame proteins ${ }^{46}$, Alaska pollack frame proteins ${ }^{47}$, jumbo squid skin gelatine ${ }^{28}$, giant squid muscle ${ }^{48}$, hoki frame proteins ${ }^{26}$, and conger eel muscle ${ }^{30}$. Activities tested are generally antioxidant and antihypertensive, but radical scavenging activities and foaming or emulsifying properties have also been considered. Similar works have been reported by other teams. Neves ${ }^{49}$ studied the impact of enzyme source and hydrolysis conditions on the molecular weight distribution of a hydrolysate of brackish water minced fish and minced shrimps. SumayaMartinez ${ }^{50}$ fractionated a shrimp frame hydrolysate by successive microfiltration $(0.45 \mu \mathrm{m})$ and ultrafiltration (30 kDa, $5 \mathrm{kDa}$ ). Unfortunately, only few details are given in these works concerning the operating conditions of the fractionation process, except the molecular weight cut-off (MWCO) of the membranes used. For instance, the volume reduction factor (VRF) is rarely precised so that the peptidic population whose activity is tested is not precisely known. It is however recognized that short peptides, below 3 or $4 \mathrm{kDa}$, usually harbour bioactive properties and the peptide size is a physico-chemical parameter - although not the unique one controlling peptide activities. Some studies discuss however the impact of ultrafiltration on peptidic 
populations on the basis of size-exclusion chromatograms $51,52,53,54$. This study was then designed to understand if UF and NF of a bioactive FPH, performed in controlled conditions, represent innovative industrial processes to obtain fractions defined by a strict range of peptide size and enriched in bioactive peptides.

\section{MATERIALS AND METHODS}

\section{Fish protein hydrolysate (FPH)}

The FPH selected for this study was PROLASTIN, a commercial product from the french SME Copalis. PROLASTIN is an elastin hydrolysate obtained by controlled proteolysis of skins from North Atlantic lean fishes (gadidae, mostly cod and pollack) followed by purification steps based on sieving, centrifugation, and discolouration. Proteolysis was performed in the SME COPALIS, using an industrial bacterial endopeptidase at optimized time, $\mathrm{pH}$ and E/S ratio. PROLASTIN is composed of polypeptides with a low molecular weight (1000 to $5000 \mathrm{Da}$ ), which makes it soluble and very digestible. Its $\mathrm{NaCl}$ content is very low $(0,79 \%$, w:w), which allows a relevant study of the biological activity of the starting hydrolysate and related fractions. It is sold as a functional ingredient for dietary complements, helping to give elasticity to tissues and limit their ageing. It is produced at industrial scale and the reproducibility of the process and final product was confirmed before fractionation.

\section{UF and NF of the FPH}

PROLASTIN was fractionated successively by UF and NF, the UF permeate being used as the feed solution for the NF step (Figure 1). Experiments were carried out on a Microlab40 pilot plant (VMA Industrie) with a maximum capacity of $5 \mathrm{~L}$ (launching tank $4.3 \mathrm{~L}+$ dead volume $0.7 \mathrm{~L}$ ). The pilot plant was equipped with tubular organic membranes (PCI Ltd), diameter $12 \mathrm{~mm}$, surface area $0.033 \mathrm{~m}^{2}$ : a NF membrane in Polyamid/Polyethersulfon (60 \% retention in $\mathrm{CaCl}_{2}$, ref. AFC40) and a UF membrane in modified Polyethersulfon (MWCO $4 \mathrm{kDa}$, ref. ESP04). The ESP04 UF membrane was chosen in the PCI range according to the molecular weight distribution of the hydrolysate. It was recently shown that a nominal MWCO between the molecular weight of the biggest and the medium sized peptides is a good choice for the fractionation of a hydrolysate ${ }^{55}$. The AFC40 NF membrane was selected as it has the poorest salt retention in the PCI range, which makes it the most appropriate to fractionate the UF permeate. A MWCO of about 300 Da has been estimated by the membrane supplier for the fractionation of organic molecules onto this NF membrane.

A $10 \mathrm{~L}$ volume of solution was prepared by mixing about exactly $100 \mathrm{~g}$ of hydrolysate powder in warm pure water. A $1 \mathrm{~L}$-aliquot was reserved for analysis. So, $9 \mathrm{~L}$ of the initial solution were filtered with the $4 \mathrm{kDa}$ membrane. At the end of the concentration process, volumes of about $8 \mathrm{~L}$ of permeate and $1 \mathrm{~L}$ of retentate were recovered. All retentate was kept for analysis, as well as a sample of about $1 \mathrm{~L}$ of permeate. The 
remaining permeate $(7 \mathrm{~L}$ ) constituted the initial solution filtered by NF in the second step of the fractionation cascade. Six liters of permeate and $1 \mathrm{~L}$ of retentate were obtained and kept for analysis. At the end of each filtration step, a sample of 10 to $50 \mathrm{~mL}$ of "instantaneous" permeate was reserved in order to estimate the retention factor at this end of the operation. Filtrations were carried out with the following operating conditions: tangential velocity $\mathrm{V}=2.5 \mathrm{~m} / \mathrm{s}$, temperature $\mathrm{T}=55^{\circ} \mathrm{C}$, transmembrane pressure $\Delta \mathrm{P}=30$ bar for UF or 35 bar for NF. The selected values for $\mathrm{V}$ and $\Delta \mathrm{P}$ were the maximum allowed by the pilot and the membrane, in order to minimize the filtration time. However, filtration times were also quite long due to the high reduction volumic factors that were reached. Thus, a fairly high temperature was chosen in order to maximize permeation fluxes, as well as to limit bacterial growth.

Previously unused UF and NF membranes were conditioned before being used according to the following sequence of washing: Water - Ultrasil 11 - water - nitric acid - water. Recovery rate in peptides in UF or NF fractions were computed as the nitrogen content of the fraction considered (retentate or permeate) divided by the sum of nitrogen contents in retentate and permeate. Nitrogen content of samples was determined by the Kjeldahl method following the norm NF EN 25663 ISO 5663 (1994).

\section{Physical and biochemical characterization of FPH, UF and NF fractions}

Colour, dry matter, $\mathrm{pH}, \mathrm{NaCl}$ content, protein content and protein recovery rates were measured or calculated following normalized procedures. $\mathrm{NaCl}$ contents were determined using a coulometric method (chlorimeter 926, Corning). Protein contents were calculated as 6.25 times the total Kjeldahl nitrogen amount. Aminogram of PROLASTIN was determined using ten milligrams of freeze-dried sample hydrolyzed for $24 \mathrm{~h}$ at $110^{\circ} \mathrm{C}$ in $200 \mu \mathrm{L}$ of $\mathrm{HCl} 6 \mathrm{~N}$ in vacuum sealed vials. The hydrolyzed sample was dried under $\mathrm{N} 2$, diluted with $2.5 \mathrm{~mL}$ of deionized water and aminoacids composition was determined using the EZ:faast ${ }^{\mathrm{TM}}$ procedure (Phenomenex, USA), consisting in a SPE step followed by derivatization and liquid-liquid extraction. The organic phase containing derivatized aminoacids was analyzed by GC-FID (Perkin Elmer Autosystem XL).. Aminoacids were identified according to their retention time and quantified using a calibration curve and an internal standard (Norvaline $200 \mu \mathrm{M}$ added to each sample). The MW distributions of the native hydrolysate and UF/NF fractions were analyzed by size exclusion chromatography in FPLC mode using a Superdex Peptide® HR 10/300 column (Amersham, fractionation range: 7000-100 Da) according to Guérard ${ }^{25}$. Samples were diluted so that the mass injected was the same for each sample. The resulting normalized chromatograms obtained in this way are representative of the peptide distribution, both in terms of molecular weight and mass composition, and are more expressive than raw chromatograms to analyze the impact of a membrane fractionation. Total areas of the chromatograms were integrated and separated into five molecular weight ranges expressed as the percentage of the total surface $(>7000,7000-3000,3000-1000,1000-300$, and < 300 Da). 


\section{Radioimmunoassay of gastrin/CCK-like peptides}

Radioimmunoassay (RIA) of gastrin/CCK-like peptides was conducted in triplicate assays using rabbit antiserum, synthetic iodine 125-radiolabeled gastrin-17 as tracer and synthetic gastrin-17 as a standard (GaskPR, Cis bio international). The principle of the assay is based on the binding competition between ${ }^{125}$ I-gastrin17 with gastrin contained in the standards or gastrin/CCK-like peptides in the samples, on a given limited number of specific binding sites on anti-gastrin antibodies. At the end of the incubation period, the amount of radiolabeled gastrin bound to the antibody is inversely proportional to the amount of non-radiolabeled gastrin/CCK originally present in the assay. The method proposed for the separation of the free and bound fractions uses an immunoprecipitant in which a second antibody has been preprecipitated in excess ${ }^{36}$. Three parameters could be examined after the analysis of the raw values: the slope coefficient of the regression line obtained with different dilutions of the FPH in comparison with the slope coefficient of the standard, the $\mathrm{ED}_{50}$ and the amount of peptide-like/mg of dry powder. Parallel slopes indicate the specific binding of peptides to antibodies. $\mathrm{ED}_{50}$ is the amount of peptides occupying $50 \%$ of the binding sites. This parameter reflects the affinity of the peptides for the antibody. The last parameter is the amount of hormone-like peptides in the dry sample. All RIA were performed in triplicate independent assays on all fractions.

\section{Radioreceptorassay of CGRP-like peptides}

The amount of CGRP-like molecules was measured using a specific radioreceptorassay. This assay used the ability of CGRP like molecules present in the hydrolysates to interact with CGRP binding to its receptors present in specific target tissues. This assay was developed using rat liver membranes and ${ }^{125}$ I labeled human CGRP. Liver membranes were prepared using male Wistar rats according to the method of Neville until step $11^{56}$. Proteins were quantified by the method of Folin-Lowry using Bovine Serum Albumine (BSA) as standard ${ }^{57}$. Incubations, in a $400 \mu \mathrm{L}$ final volume, were performed at $22^{\circ} \mathrm{C}$ for 1 hour $^{58}$. At the end of the incubation, bound and free ligands were separated by centrifugation in a solution containing $2 \%$ BSA. Each batch was tested at four increasing protein concentrations, and only the straight lines presenting slopes similar to that obtained with the standard hormone (0.01-1 ng/assay) were considered as positive. The receptor binding ability of each purified fraction was determined in triplicate independent assays and used to calculate the quantity (pg) of CGRP like activity per mg of protein. Data were also expressed as the amount of protein $(\mathrm{mg})$ that induced a $50 \%$ inhibition of the initial CGRP binding to rat liver membranes $\left(\mathrm{ED}_{50}\right)$.

\section{Antioxidant activity}

\section{DPPH radical scavenging activity}

Radical scavenging activity was measured according to the procedure reported by Morales and Jimenez-Perez

${ }^{59}$. An aliquot of sample $(200 \mu \mathrm{L})$ was added to $1 \mathrm{~mL}$ of a daily-prepared solution of 1,1-Diphenyl-2-Picryl- 
Hydrazyl (DPPH) at a $74 \mathrm{mg} . \mathrm{L}^{-1}$ concentration in ethanol. The mixture was shaken for 1 hour at $25^{\circ} \mathrm{C}$. The sample was centrifuged at $10000 \mathrm{x}$ g for $5 \mathrm{~min}$ and absorption of the supernatant was measured at $520 \mathrm{~nm}$. The $\mathrm{DPPH}^{*}$ concentration in the reaction medium was calculated from the calibration curve, determined by linear regression:

$$
[D P P H]_{t}=0.0241\left(A_{520 ~ n m}\right)+0.022\left(r^{2}=0.9995\right)
$$

The radical scavenging activity of the sample was expressed as percentage disappearance of DPPH',

DPPH radical scavenging activity $(\%)=\left(1-\left([\mathrm{DPPH}]_{\mathrm{t}} /[\mathrm{DPPH}]_{\mathrm{H} 2 \mathrm{O}}\right)^{*} 100\right)$

where $[\mathrm{DPPH}]_{\mathrm{H} 2 \mathrm{O}}$ is the concentration of DPPH in the presence of water instead of hydrolysate. In vitro DPPH radical scavenging activity was determined in triplicate independent assays and expressed as $\mathrm{AC}_{50}$, corresponding to the concentration of hydrolysate $\left(\mathrm{mg} \cdot \mathrm{mL}^{-1}\right.$ protein determined according to the Kjeldahl method) able to scavenge $50 \%$ of DPPH radical.

\section{Quantification of antioxidant activity using the beta-carotene/linoleate model system}

The antioxidant activity was determined using the beta-carotene/linoleate model system as described by Marco $^{60}$ with some slight modifications. Five $\mathrm{mL}$ aliquots of a beta-carotene-linoleate emulsion were transferred to glass tubes, containing $200 \mu \mathrm{L}$ of sample at several protein concentrations in MilliQ water. All samples were stirred and incubated simultaneously for 2 hours at $50^{\circ} \mathrm{C}$. Absorbance values at $470 \mathrm{~nm}$ of samples and controls (water and BHA) were recorded every $30 \mathrm{~min}$ with a microplate reader (SPECTRAmax PLUS 384, Molecular Devices). The antioxidant activity gives an estimate of the relative protection of each sample against the oxidation of linoleate, observed by the bleaching extent of the beta-carotene-linoleate emulsion. The antioxidant activity was calculated as:

$$
\text { Antioxidant activity }=\left(\mathrm{OD}_{\mathrm{t}=60 \mathrm{~min}} / \mathrm{OD}_{\mathrm{t}=0 \mathrm{~min}}\right) * 100
$$

In vitro antioxidant activity was determined in triplicate independent assays and expressed as $\mathrm{AC}_{50}$, corresponding to the concentration of hydrolysate $\left(\mathrm{mg} . \mathrm{mL}^{-1}\right.$ protein determined according to the Kjeldahl method) inducing $50 \%$ of antioxidant activity.

\section{ACE-1 inhibition assay}

In vitro inhibition of ACE-1 was assayed following the spectrophotometrical Holmquist method ${ }^{61}$. Inhibition was calculated from triplicate independent assays and expressed as $\mathrm{IC}_{50}$ and maximal \% inhibition. $\mathrm{IC}_{50}$ corresponds to the concentration of hydrolysate or fraction inducing 50\% inhibition of ACE-1 activity. Captopril 21.7.10 $\mu \mathrm{g} \cdot \mathrm{mL}^{-1}(0.1 \mu \mathrm{M})$ was used as a reference inducing $100 \%$ inhibition. 


\section{RESULTS AND DISCUSSION}

\section{Physical, chemical and biochemical properties of FPH and fractions}

Colour, dry matter, $\mathrm{pH}, \mathrm{NaCl}$ content, protein content, protein recovery rates and aminograms of PROLASTIN and related UF and NF fractions are given in Tables 1 and 2. Aminograms of PROLASTIN and related fractions revealed a balanced composition and confirmed their high nutritional value (Table 2). It is of interest to note that peptides containing PRO, HYP, ASP and GLU were concentrated in the UF and NF retentates compared to the unfractionated hydrolysate and UF permeate respectively (Table 2), suggesting that the presence of specific amino-acids may influence the interactions of peptides with the peptide layer in contact with the membranes.

\section{Peptidic profiles and impact of the fractionation on MW distributions}

PROLASTIN is a highly hydrolyzed peptide mix, where $98.6 \%$ (in mass) of peptides had a molecular weight lower than 4,000 $\mathrm{Da}$ (Table 3). Ultrafiltration of the crude hydrolysate, as well as nanofiltration of the ultrafiltrated permeate constituted very efficient processes to desalt the peptide fractions (Table 1). The impact of the 2-steps UF-NF process on the peptidic populations of PROLASTIN, in term of yield obtained in the various fractions and peptide size repartition relatively to the MWCO of the membranes, was described in detail in a previous publication ${ }^{55}$. The objective here was to process crude extracts in conditions representative of an industrial operation to compare the biological activities of the fractions relatively to their peptide population content. Thus, fairly concentrated solutions were processed (about exactly $100 \mathrm{~g} . \mathrm{L}^{-1}$ ) at a high volume reduction factor (VRF) in order to obtain four fractions with compositions as different as possible (Table 3):

- the UF retentate, enriched in peptides above 4,000 $\mathrm{Da}$;

- the UF permeate, poor in peptides above 4,000 Da;

- the NF retentate, poor in peptides above 4,000 Da and rich in peptides above ca $300 \mathrm{Da}$;

- the NF permeate, poor in peptides above ca $300 \mathrm{Da}$.

This study demonstrated that membranes do not carry out sharp separations, some MW classes being found in several fractions. Thus, the NF retentate still contained about $22 \%$ of peptides below $300 \mathrm{Da}$. More dramatically, the UF retentate contained a large amount of peptides (93\% in weight) below 4,000 Da (the nominal MWCO of the membrane) even though high VRF were reached. NF and UF permeate fluxes are given on Figure 2 as a function of time in order to illustrate the effect of dynamic cake formation on filtration behaviour. Fluxes values and their similar decrease in the course of time are discussed elsewhere ${ }^{55}$. One important result of this study is that it is clearly misleading to characterise the fractions obtained by membrane filtration according only to the MW cut-off of the membrane, as it is currently done in the literature $(>4,000$ Da for the UF retentate, 300-4,000 Da for the NF retentate, and so on). 
Presence of gastrin/CCK-like peptides in FPH and fractions

Dosage of gastrin/CCK-like peptides in the fractions is presented in Table 4. Gastrin/CCK-like peptides were identified in the unfractionated hydrolysate and in all UF and NF fractions. The curve slope measured with the unfractionated hydrolysate was very close to that of standard ${ }^{125}$ I-gastrin, indicating the presence of peptides binding specifically to gastrin antibodies. The amount of gastrin/CCK-like peptides present in the unfractionated hydrolysate was in the range of data previously published for fish and shellfish hydrolysates ${ }^{36}$, the best activity (about $4 \mathrm{pg}$ of gastrin-like peptides) being obtained with a shrimp hydrolysate fraction containing peptides between 4000 and $1000 \mathrm{Da}$. The $\mathrm{ED}_{50}$ value of the unfractionated hydrolysate was very high, which is characteristic of a low binding affinity. UF and NF of PROLASTIN resulted in variations in the curve slope and dilution of gastrin/CCK-like peptides, suggesting that these processes do not allow an enrichment in peptides of interest. Interestingly, the $\mathrm{ED}_{50}$ measured for $\mathrm{UF}$ and NF retentates was much lower than that of the unfractionated hydrolysate, suggesting that the gastrin antibody binding affinity of peptides present in these fractions was increased. However, the main conclusion of this dosage is that UF or NF fractionations do not allow to concentrate gastrin/CCK-like peptides in selected fractions.

\section{Presence of CGRP-like peptides in FPH and fractions}

The dosage of CGRP-like peptides in the fractions demonstrated an important increase (10 fold) of the CGRPlike activities in the UF permeate, relatively to the crude extract (Table 5). Nanofiltration of the UF permeate did not allow a higher concentration of CGRP-like peptides. The highest activity found in the UF permeate was also confirmed by the $\mathrm{ED}_{50}$ values (Table 5). The best interaction was observed with the UF permeate with only $3.6 \mathrm{mg}$ of dry weight sample necessary to obtain a 50\% inhibition of the maximal binding of radiolabelled CGRP; this value corresponded to a 5.2 fold affinity increase compared to the unfractionated hydrolysate. Moreover, this $\mathrm{ED}_{50}$ value could not be increased by a subsequent NF process. Therefore, it appears that UF allows to concentrate CGRP-like peptides in the UF permeate, with an important increase of affinity for CGRP receptors, as measured using the binding displacement of ${ }^{125}$ I-CGRP.

\section{Antioxidant activities}

The in vitro antioxidant activities of the PROLASTIN hydrolysate and fractions are presented in Table 6. Before fractionation, PROLASTIN showed a high DPPH radical scavenging activity with an $\mathrm{AC}_{50}$ of 24.7 $\mathrm{mg} \cdot \mathrm{mL}^{-1}$. This result suggests that PROLASTIN contains peptides reacting with free radicals to form more stable products. PROLASTIN also showed a potent antioxidant activity, with an $\mathrm{AC}_{50}$ of 0.12 g. $\mathrm{L}^{-1}$. Fractionation of PROLASTIN induced a weak loss of antioxidant and DPPH radical scavenging activities. 
According to Pihlanto ${ }^{62}$, the structure-activity relationship of the antioxidant mechanism of protein hydrolysates is not yet fully understood. The antioxidant activity seems to be inherent to the characteristic amino acid sequences of the peptides, depending both on the amino acid composition of the substrate and on the specificity of the protease used in the process. We in fact observed a different result fractionating a cod protein hydrolysate, as the antioxidant activity of UF fractions was superior to that of the unfractionated hydrolysate (data not shown as the $\mathrm{NaCl}$ content of this hydrolysate was > to 5\% w:w). A stepwise fractionation of a protein hydrolysate using membrane separation by molecular weight cut-off adapted to the peptide composition of hydrolysate may thus provide an effective mean to concentrate antioxidative peptides, but the mechanisms allowing a concentration in antioxidant peptides have yet to be clarified and the process optimized. Changing the selectivity of the membrane, not only in term of peptide size but also in term of aromatic selectivity, could be of interest to concentrate antioxidant peptides.

\section{ACE-1 inhibitory activity of FPH and fractions}

In vitro ACE-1 inhibitory activities of PROLASTIN and fractions are summarized in Table 7. PROLASTIN, UF and NF fractions exerted a moderate ACE-1 inhibition when compared to control pharmacological inhibitors (captopril, $100 \%$ inhibition at $21.7 .10^{-3} \mu \mathrm{g} \cdot \mathrm{mL}^{-1}(100 \mathrm{nM}), \mathrm{IC}_{50}=4.34 .10^{-3} \mu \mathrm{g} \cdot \mathrm{mL}^{-1}(0.02 \mu \mathrm{M})$. ACE-1 inhibition was in the range of activities previously measured with enzymatic hydrolysates obtained from other fish proteins $\left(\mathrm{IC}_{50}\right.$ ranging from 52 to $63 \mu \mathrm{g}$ of peptides per $\mathrm{mL}$ for unfractionated and fractionated PROLASTIN, $\mathrm{IC}_{50}=44 \mu \mathrm{g}$ peptides per $\mathrm{mL}$ for ultrafiltrated $(<10 \mathrm{kDa})$ Pacific hake peptides $\left.{ }^{63}\right)$. These data confirm that FPH constitute interesting sources of ACE-1 inhibitory peptides and reinforce the common view that the in vitro ACE inhibitory activity is mostly dependent on peptide size rather than on fish species source. Ultrafiltration of PROLASTIN did not result in drastic changes in ACE inhibitory activity, contrary to previous observations obtained on Pacific hake peptides. Several hypotheses can be drawn to explain why UF had only a weak impact on ACE inhibitory activities. The presence of a large amount of peptides $<4 \mathrm{kDa}$ in the UF retentate demonstrates that the unfractionated hydrolysate was already rich in low MW peptide, hardly separated by UF as only peptides with a MW $<400$ Da can freely cross the UF membrane. For peptides ranging from $400 \mathrm{Da}$ to $4 \mathrm{kDa}$, the ability to cross the UF membrane is directly dependent upon their $\mathrm{MW}$, the lower crossing easier. It can thus be considered that the UF permeate contained a peptide population with a MW distribution centred on low MW, and that the short peptides were not all removed from the UF retentate, in spite of a high UF volumic reduction factor. In the same way, the NF retentate still contained an important proportion of peptides < $300 \mathrm{Da}$. The possibility of synergistic ACE-inhibitory effects between peptides with different MW, and the potential oxidative degradation of peptides during the UF process, performed at $55^{\circ} \mathrm{C}$, can not also be excluded. NF only weakly enhanced the activity of ultrafiltrated hydrolysates, with no important optimization regarding the development costs of an industrial NF process. 


\section{CONCLUSION}

This study was designed to highlight the impact of controlled UF and NF on the stability of biological activities of an industrial FPH, and to understand if fractionation could improve its content in bioactive peptides. One important result arising from UF and NF fractionation performed in this study is that it is misleading to characterise the fractions obtained by membrane filtration according only to the MW cut-off of the membrane, even when high volume reduction factor are achieved, as some MW classes can be found in different fractions. We also interestingly observed that fractionation allowed the concentration of peptides containing glutamate, aspartate, proline and hydroxyproline in the UF and NF retentates. The data obtained in this study suggest that UF and NF fractionation allow to obtain fractions rich in bioactive peptides, depending on the composition of the starting hydrolysate and the activity studied. In our study, UF had a positive impact on the presence of CGRP-like peptides in the fractions but not on gastrin/CCK-like peptides. Our data demonstrated that fractionation of a FPH exerting a potent antioxidant activity does not systematically allow an increase of this activity, but changing the selectivity of the membrane, not only in term of peptide size but also in term of selectivity for aromatic amino-acids, may be of interest to concentrate antioxidant peptides. It was described in the first part of this article that PROLASTIN is a highly hydrolyzed peptide mix and this could explain the weak impact of fractionation on the biological activities. In this view, it could be of high interest to prepare a weakly hydrolyzed PROLASTIN sample, to fractionate it and compare the data to those obtained in this study. Our data demonstrated that the knowledge of the MW distribution is of high importance to select the MW cut-off of the membranes but insufficient to define a strategy to obtain fractions enriched in bioactive peptides. In this view, defining the relations existing between the physico-chemical properties of a hydrolysate (charge, sequence, peptides size, and MW distribution) and its biological activities, as well as the influence of the fractionation process (MW cut-off, vrf, delta $\mathrm{P}, \ldots$ ) on the distribution of peptide populations will be of great interest for industrials developing functional ingredients ${ }^{64}$.

\section{ACKNOWLEDGEMENTS}

This study was performed within the SEAFOODplus European Integrated Programme (http://www.seafoodplus.org) as part of the "Propephealth" project 4.1. The Région Bretagne is thankfully acknowledged for a post-doctoral research grant within the ACTIVEMB project.

\section{REFERENCES}

1. Deal CL and Moskowitz RW, Nutraceuticals as therapeutic agents in osteoarthritis. The role of 
glucosamine, chondroitin sulfate, and collagen hydrolysate. Rheum Dis Clin N Am 25(2): 379-395 (1999).

2. Meisel H, Biochemical properties of bioactive peptides derived from milk proteins: potential nutraceuticals for food and pharmaceutical applications. Livest Prod Sci 50:125-138 (1997).

3. Tiruppathi C, Kulanthaivel P, Ganapathy V, Leibach FH, Evidence for tripeptide/H+ co-transport in rabbit renal brush-border membrane vesicles. Biochem J 268(1):27-33 (1990).

4. Aito-Inoue M, Lackeyram D, Fan MZ, Sato K, Mine Y, Transport of a tripeptide, Gly-Pro-Hyp, across the porcine intestinal brush-border membrane. J Pept Sci 13(7): 468-474 (2007).

5. Satake M, Enjoh M, Nakamura Y, Takano T, Kawamura Y, Arai S, Shimizu M, Transepithelial transport of the bioactive tripeptide, Val-Pro-Pro, in human intestinal Caco-2 cell monolayers. Biosci Biotechnol Biochem .66(2): 378-384 (2002).

6. Quiros A, Davalos A, Lasuncion MA, Ramos, M, Recio I. Bioavailability of the antihypertensive peptide LHLPLP: Transepithelial flux of HLPLP, Int Dairy J 18(3) : 279-286 (2008).

7. Fitzgerald JF, Kottmeier PK, Adamsons RJ, Butt KM, Hochman RA, Dennis C, Effect of hypertonic solutions on intestinal mucosal integrity. Surg Forum 19:297-299 (1968).

8. Takeda T, Sakata M, Minekawa R, Yamamoto T, Hayashi M, Tasaka K, Human milk induces fetal small intestinal cell proliferation : involvement of a different tyrosine kinase signaling pathway from epidermal growth factor receptor. $J$ Endocrinol 181(3):449-457. (2004).

9. LeBlanc JG, Matar C, Valdez JC, LeBlanc J, Perdigon G, Immunomodulating effects of peptidic fractions issued from milk fermented with Lactobacillus helveticus. J Dairy Sci 85(11):2733-2742 (2002).

10. Pellegrini A, Hulsmeier AJ, Hunziker P, Thomas U, Proteolytic fragments of ovalbumin display antimicrobial activity. Biochim Biophys Acta 1672(2):76-85 (2004).

11. Manso MA, Escudero C, Alijo M, Lopez-Fandino R, Platelet aggregation inhibitory activity of bovine, ovine, and caprine kappa-casein macropeptides and their tryptic hydrolysates. J Food Prot 65(12):1992-1996 (2002).

12. FitzGerald RJ, Murray BA, Walsh DJ, Hypotensive peptides from milk proteins, J Nutr 134(4):980988 (2004).

13. Kim SE, Kim HH, Kim JY, Kang YI,Woo HJ, Lee HJ, Anticancer activity of hydrophobic peptides from soy proteins. Biofactors 12(1-4):151-155 (2000).

14.Guérard F, Sellos D and Le Gal Y, Fish and Shellfish Upgrading, traceability. Adv Biochem Eng Biotechnol 96: 127-163 (2005).

15. Picot L, Bordenave S, Didelot S, Fruitier-Arnaudin I, Sannier F, Thorkelsson G, Bergé JP, Guérard F, Chabeaud A and. Piot JM, Antiproliferative activity of fish protein hydrolysates on human breast cancer cell lines. Process Biochem 41(5):1217-1222 (2006). 
16. Hydrofish (1997-2000), European project FAIR-CT 97-3097.

17. Byun HG and Kim SK, Structure and activity of angiotensin I converting enzyme inhibitory peptides derived from Alaskan pollack skin. J Biochem Mol Biol 35(2):239-243 (2002).

18. Je JY, Park PJ, Kwon JY and Kim SK, A Novel Angiotensin I Converting Enzyme Inhibitory Peptide from Alaska Pollack (Theragra chalcogramma) Frame Protein Hydrolysate. J Agric Food Chem 52(26): $7842-7845$ (2004).

19. Qian ZJ, Je JY and Kim SK, Antihypertensive Effect of Angiotensin I Converting Enzyme-Inhibitory Peptide from Hydrolysates of Bigeye Tuna Dark Muscle, Thunnus obesus. J Agric Food Chem 55(21):8398-8403 (2007).

20. Fujii M, Matsumura N, Mito K, Shimizu T, Kuwahara M, Sugano S and Karaki H, Antihypertensive effects of peptides in autolysate of bonito bowels on spontaneously hypertensive rats. Biosci Biotechnol Biochem 57(12):2186-2188 (1993).

21. Karaki H, Kuwahara M, Sugano S, Doi C, Doi K, Matsumura N and Shimizu T, Oral administration of peptides derived from bonito bowels decreases blood pressure in spontaneously hypertensive rats by inhibiting angiotensin converting enzyme. Comp Biochem Physiol C 104(2):351-353 (1993).

22. Fujita, Yokoyama K, Yasumoto R and Yoshikawa M, Antihypertensive effect of thermolysin digest of dried bonito in spontaneously hypertensive rat. Clin Exp Pharmacol Physiol Suppl 22(1):S304-305 (1995).

23. Kawasaki T, Seki E, Osajima K, Yoshida M, Asada K, Matsui T and Osajima Y, Antihypertensive effect of valyl-tyrosine, a short chain peptide derived from sardine muscle hydrolyzate, on mild hypertensive subjects. J Hum Hypertens 14(8):519-523 (2000).

24. Diplock AT, Charleux JL, Crozier-Willi G, Kok FG, Rice-Evans C, Roberfroid M, Stahl W, VinaRibes $\mathrm{J}$ and Breslin L; Functional food science and defence against reactive oxidative species. Functional food science in Europe, Br J Nut. 80 (SUP1): 77-112 (1998).

25. Guérard F, Sumaya-Martinez MT, Laroque D, Chabeaud A and Dufossé L, Optimization of free radical scavenging activity in the hydrolysis of shrimp processing discards by Response Surface Methodology. Process Biochem 42: 1486-1491 (2007).

26. Kim Y, Je JY and Kim SK, Purification and characterization of antioxidant peptide from hoki (Johnius belengerii) frame protein by gastrointestinal digestion, J Nutr Biochem 18(1): 31-38 (2007).

27. Je JY, Qian ZJ, Byun HG, and Kim SK, Purification and characterization of an antioxidant peptide obtained frum tuna backbone protein by enzymatic hydrolysis. Process Biochem 42: 840-846(2007).

28. Mendis E, Rajapakse N, Byun HG and Kim SK, Investigation of jumbo squid (Dosidicus gigas) skin gelatin peptides for their in vitro antioxidant effects. Life Sciences 77(17):2166-2178 (2005a).

29. Mendis E, Rajapakse N and Kim SK, Antioxidant properties of a radical-scavenging peptide purified from enzymatically prepared fish skin gelatin hydrolysate. J Agric Food Chem 53: $581-587$ (2005b).

30. Ranathunga. S, Rajapakse N and Kim SK, Purification and characterization of antioxidative peptide 
derived from muscle of conger eel (Conger myriaster), Eur Food Res Technol 222(3-4): 310-315 (2006). 31. Klompong V, Benjakul S, Kantachote D and Shahidi F, Antioxidative activity and functional properties of protein hydrolysate of yellow stripe trevally (Selaroides leptolepis) as influenced by the degree of hydrolysis and enzyme type. Food Chemistry 102(4): 1317-1327 (2007).

32. Suetsuna K, Antioxidant peptides from the protease digest of prawn (Penaeus japonicus) muscle. Marine Biotech 2: 5-10 (2000).

33. Thiansilakul Y, Benjakul S and Shahidi F, Antioxidative activity of protein hydrolysate from round scad muscle using alcalase and flavourzyme. J Food Biochem 31: 266-287 (2007).

34. Cancre I, Ravallec R, Van Wormhoudt A, Stenberg E, Gildberg A and le Gal Y, Secretagogues and Growth Factors in Fish and Crustacean Protein Hydrolysates. MarBiotechnol 1(5):489-494 (1999).

35. Ravallec-Plé R, Charlot C, Pires C, Batista I, Van Wormhoudt A, Le Gal Y and Fouchereau-Peron M, The presence of bioactive peptides in hydrolysates prepared from processing wastes of sardine (Sardina pilchardus). J Sci Food Agric 81: 1120-1125 (2001).

36. Ravallec-Plé R and Van Wormhoudt A, Secretagogues activities in cod (Gadus morhua) and shrimp (Penaeus aztecus) extracts and alcalase hydrolysates determined in AR4-2J pancreatic tumour cells. Comp Biochem Physiol Part B: Biochem Mol Biol 134(4): 669-679 (2003).

37. Johnson LRE, Copeland EM and Dudrick SJ, Luminal gastrin stimulate growth of the distal intestine. Scand J Gastroenterol 13(49): 95 (1978).

38. Beinfeld MC, Cholecystokinin/gastrin. In Psychopharmacology : The fourth generation of progress (F. E. Bloom and D. Kupfer ed.), Raven Press : 585-594 (1995).

39. Bray GA, Afferent signals regulating food intake. Proc Nutr Soc 59: 373-384 (2000).

40. Thavanathan R and Volkoff $\mathrm{H}$, Effects of amylin on feeding of goldfish: Interactions with CCK. Regul Peptides 133 : 90 - 96 (2006).

41. Amara SG, Jonas V, Rosenfeld MG, Ong ES and Evans RM, Alternative RNA processing in calcitonin gene expression generates mRNAs encoding different polypeptide products. Nature 298: 240244 (1982).

42. Brain SD and Grant AD, Vascular actions of Calcitonin Gene-Related Peptide and adrenomedullin. Physiol Rev 84: 903-934(2004).

43. Lenz HJ, Mortrud MT, Vale WW, Rivier JE and Brown MR, Calcitonin gene related peptide acts within the central nervous system to inhibit gastric acid secretion. Regul Peptides 9: 271-277 (1984).

44. Fouchereau-Peron M, Duvail L, Michel C, Gildberg A, Batista I and Le Gal Y, Isolation of an acid fraction from a fish protein hydrolysate with a CGRP-like biological activity. Biotechnol Appl Biochem 29: 87-92 (1999).

45. Martinez Alvarez O, Delannoy C, Guimas L and Fouchereau-Peron M, The occurrence of CGRP like molecule in a siki (Centroscymnus coelolepsis) hydrolysate of industrial origin. J Agric Food Chem 55:5469-5475 (2007). 
46. Jeon YJ, Byun HG and Kim SK, Improvement of functional properties of cod frame protein hydrolysates using ultrafiltration membranes. Process Biochem 35: 471-478 (1999).

47. Je JY, Park PJ and Kim SK, Antioxidant activity of a peptide isolated from Alaska pollack (Theragra chalcogramma) frame protein hydrolysate. Food Res Int 38(1): 45-50 (2005).

48. Rajapakse N, Purification and in vitro antioxidative effects of giant squid muscle peptides on free radical-mediated oxidative systems. J Nutr Biochem 16: 562-569 (2005).

49. Neves RAM, Mira NVM and Marquez UML, Characterization of enzymatic fish hydrolysates. Ciência e Tecnologia de Alimentos 24(1): 101-108 (2004).

50. Sumaya-Martinez MT, Doctoral Thesis, Université de Bretagne Occidentale, France (in french) (2004).

51. Vandanjon L, Johannsson R, Derouiniot M, Jaouen P and Bourseau P, Concentration and purification by ultrafiltration of marine peptides solutions, J. Food Eng. 83: 581-589 (2007).

52. Chabeaud A, Vandanjon L, Bourseau P, Jaouen P and Guérard F, Fractionation by ultrafiltration of a saithe protein hydrolysate (Pollachius virens): effect of material and molecular weight cut-off on the membrane performances, J. Food Eng., 91: 408-414, (2009).

53. Chabeaud A, Vandanjon L, Bourseau P, Jaouen P, Chaplain-Derouiniot $\mathrm{M}$ and Guérard F, Performances of ultrafiltration membranes for fractionating a fish protein hydrolysate: Application to the refining of bioactive peptidic fractions, Sep. Pur. Technol., 66: 463-471(2009).

54. Vandanjon L, Grignon M, Courois E, Bourseau P and Jaouen P, Fractionating of fish hydrolysates by a cascade of ultrafiltration and nanofiltration, J. Food Eng., 95: 36-44 (2009).

55. Bourseau P, Vandanjon L, Jaouen P, Chaplain-Derouiniot M, Massé A, Guérard F, Chabeaud A, Fouchereau-Péron M, Le Gal Y, Ravallec-Plé R, Bergé JP, Picot L, Piot JM, Batista I, Thorkelsson G, Delannoy C, Jakobsen G, Johansson I, Fractionation of fish protein hydrolysates by ultrafiltration and nanofiltration: impact on peptidic populations. Desalination 244: 303-320 (2009).

56. Neville DMJ, Isolation of an organ specific protein antigen from cell surface membrane rat liver. Biochim Biophys Acta 154: 540-552 (1968).

57. Lowry OM, Rosenbrough WJ, Farr AL and Randall RJ, Protein measurement with folin phenol reagent. J Biol Chem 193: 265-275 (1951).

58. Yamaguchi A, Chiba T, Yamatani T, Inui T, Morishita T, Nakamura A, Kadowaki S, Fukase M and Fujita T, Calcitonin gene-related peptide stimulates adenylate cyclase activation via guanine nucleotidedependent process in rat liver plasma membranes. Endocrinol 123: 2591-2597 (1988).

59. Morales FJ and Jiménez-Pérez S, Free radical scavenging capacity of Maillard reaction products as related to colour and fluorescence. Food Chem 72(1): 119-125 (2001).

60. Marco GJ, A rapid method for evaluation of antioxidants. J Am Oil Chem Soc 45: 594-598 (1968).

61. Holmquist B, Bunning P, Riordan J, A continuous spectrophotometric assay for angiotensin converting enzyme. J Anal Chem 95: 540-548 (1979). 
62. Pihlanto A, Antioxidative peptides derived from milk proteins. Int Dairy J 16:1306-1314 (2006).

63. Cinq-Mars CD and Li-Chan EC, Optimizing angiotensin I-converting enzyme inhibitory activity of Pacific hake (Merluccius productus) fillet hydrolysate using response surface methodology and ultrafiltration. J Agric Food Chem 55(23): 9380-9388 (2007).

64. Kitts DD, Weiler K, Bioactive proteins and peptides from food sources. Applications of bioprocesses used in isolation and recovery. Curr Pharm Des 9(16):1309-1323 (2003). 
FIGURES

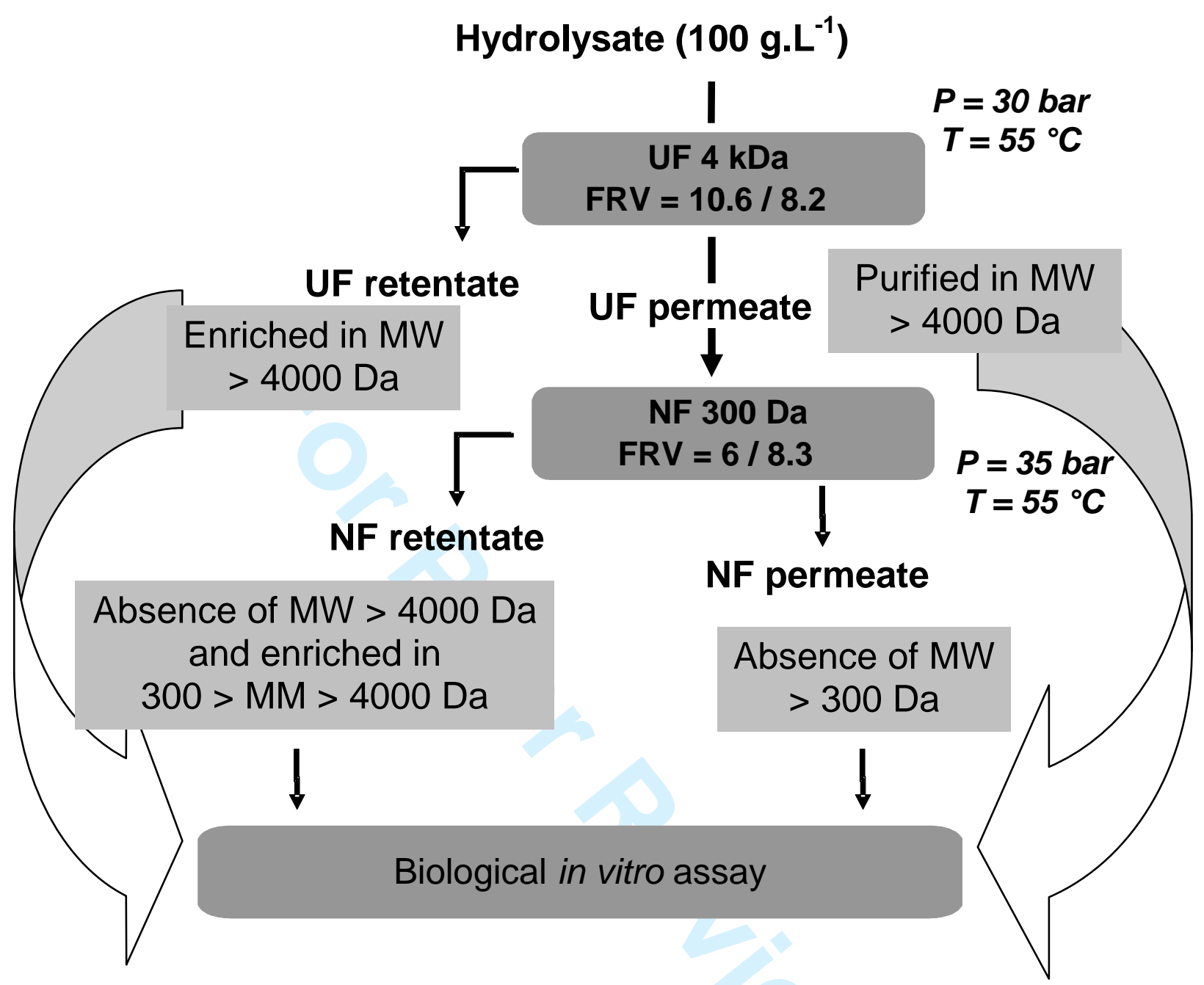

Figure 1. The ultrafiltration-nanofiltration sequence. 


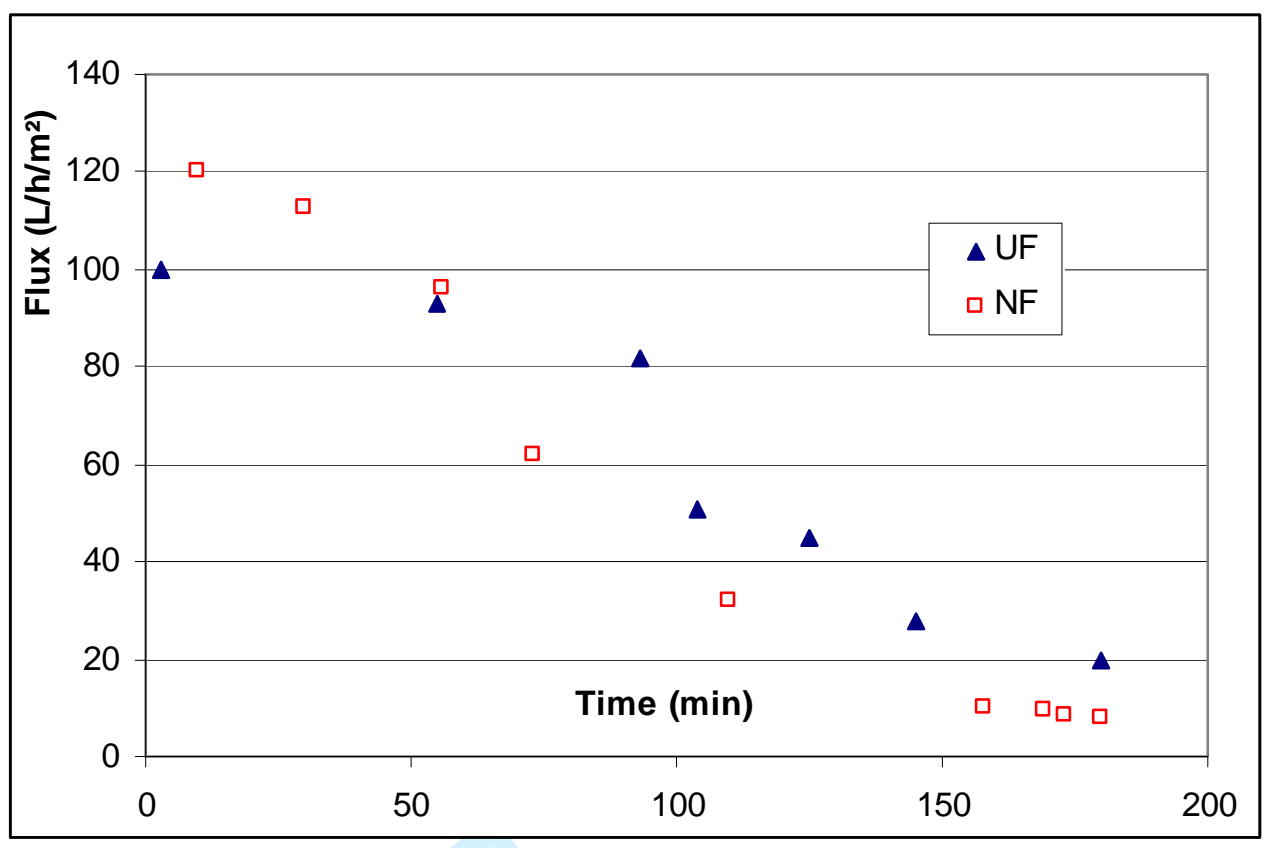

Figure 2. Flux evolution with time for the UF and NF steps, PROLASTIN hydrolysate (from Bourseau et al., Desal. 2009 [55]) 


\begin{tabular}{|c|c|c|c|c|c|c|}
\hline & Colour & $\begin{array}{c}\text { Dry matter } \\
(\mathbf{D M}) \mathbf{g . L} \mathbf{L}^{-1}\end{array}$ & $\mathbf{p H}$ & $\begin{array}{c}\text { NaCl/ DM } \\
(\boldsymbol{\%})\end{array}$ & $\begin{array}{c}\text { Protein/ } \\
\text { DM (\%) }\end{array}$ & $\begin{array}{c}\text { Protein recovery } \\
\text { rate \%* }\end{array}$ \\
\hline Unfractionated hydrolysate & Yellow orange & 111.50 & 8 & 0.79 & 88.5 & 31 \\
\hline Retentate UF 4 Kd & Yellow orange & 355.25 & 7.9 & 0.06 & 90.9 & 69 \\
\hline Permeate UF 4 Kd & Yellow & 85 & 7.9 & 1.06 & 81.6 & 77 \\
\hline Retentate NF 300 Da & Yellow & 325 & 7.9 & 0.09 & 91.3 & 23 \\
\hline Permeate NF 300 Da & Yellow & 25.55 & 8.1 & 3.60 & 71.1 & \\
\hline
\end{tabular}

Table 1. Physical properties of the PROLASTIN hydrolysate and its UF and NF fractions. * Protein recovery rate was determined in reference to the unfractionated hydrolysate for the ultrafiltration and in reference to the UF permeate for the NF fractions.

\begin{tabular}{|c|c|c|c|c|c|c|c|c|c|c|c|c|c|c|c|c|c|}
\hline & \multicolumn{17}{|c|}{ mmol.g $\mathrm{g}^{-1}$ of dry sample } \\
\hline & ALA & GLY & VAL & LEU & ILE & THR & SER & PRO & ASP & MET & HYP & GLU & PHE & LYS & HIS & HLY & TYR \\
\hline $\begin{array}{l}\text { Unfractionated } \\
\text { hydrolysate }\end{array}$ & 0.71 & 1.83 & 0.25 & 0.35 & 0.18 & 0.29 & 0.46 & 0.56 & 0.40 & 0.13 & 0.22 & 0.43 & 0.14 & 0.12 & 0.05 & 0.00 & 0.04 \\
\hline Retentate UF $4 \mathrm{Kd}$ & 0.65 & 2.16 & 0.26 & 0.27 & 0.20 & 0.30 & 0.47 & 0.78 & 0.64 & 0.11 & 0.40 & 0.64 & 0.12 & 0.14 & 0.06 & 0.02 & 0.04 \\
\hline Permeate UF 4 Kd & 0.72 & 1.62 & 0.29 & 0.37 & 0.22 & 0.29 & 0.44 & 0.49 & 0.43 & 0.12 & 0.20 & 0.56 & 0.13 & 0.15 & 0.06 & 0.01 & 0.05 \\
\hline Retentate NF $300 \mathrm{Da}$ & 0.70 & 1.85 & 0.31 & 0.33 & 0.23 & 0.31 & 0.44 & 0.62 & 0.52 & 0.12 & 0.27 & 0.68 & 0.13 & 0.16 & 0.07 & 0.01 & 0.04 \\
\hline Permeate NF $300 \mathrm{Da}$ & 0.88 & 1.25 & 0.28 & 0.51 & 0.19 & 0.27 & 0.47 & 0.27 & 0.21 & 0.11 & 0.04 & 0.25 & 0.16 & 0.13 & 0.06 & 0.01 & 0.05 \\
\hline
\end{tabular}

Table 2. Amino-acid composition of unfractionated PROLASTIN and related UF and NF fractions. (ALA : alanine, GLY : glycine, VAL : valine, LEU : leucine, ILE : isoleucine, THR : threonine, SER : serine, PRO : proline, ASP : aspartic acid, MET : methionine, HYP : hydroxy proline, GLU : glutamic acid, PHE : phenylalanine, LYS : lysine, HIS : histidine, HLY : hydroxy lysine, TYR : tyrosine). 


\begin{tabular}{|c|c|c|c|c|c|}
\hline Molecular weight (Da) & $\mathbf{7 0 0 0}$ & $\mathbf{7 0 0 0}-\mathbf{4 0 0 0}$ & $\mathbf{4 0 0 0}-\mathbf{1 0 0 0}$ & $\mathbf{1 0 0 0}-\mathbf{3 0 0}$ & $<\mathbf{3 0 0}$ \\
\hline Unfractionated hydrolysate & 0.23 & 1.18 & 23.28 & 45.78 & 29.54 \\
\hline Retentate UF 4 Kd & 3.98 & 3.48 & 41.15 & 41.55 & 9.84 \\
\hline Permeate UF 4 Kd & 0.02 & 0.08 & 13.9 & 49.66 & 36.33 \\
\hline Retentate NF 300 Da & 4.85 & 0.09 & 17.49 & 55.78 & 21.78 \\
\hline Permeate NF 300 Da & 0 & 0 & 0.74 & 17.79 & 81.47 \\
\hline
\end{tabular}

Table 3. Molecular weight distribution of peptides contained in PROLASTIN and related UF and NF fractions (\% repartition) 


\begin{tabular}{|c|c|c|c|}
\hline FRACTION & Slope & $\begin{array}{c}\text { pg of gastrin/CCK- } \\
\text { like peptides } \\
\text { per mg dry weight }\end{array}$ & $\begin{array}{c}\text { ED }_{\mathbf{5 0}} \\
\text { (mg dry weight) }\end{array}$ \\
\hline${ }^{\mathbf{1 2 5} \text { I-G17 }}$ & -41.99 & - & 11.03 \\
\hline Unfractionated hydrolysate & -38.87 & 1.30 & 5.97 \\
\hline Retentate UF 4 Kd & -58.86 & 0.98 & 9.03 \\
\hline Permeate UF 4 Kd & -48.83 & 0.93 & 5.99 \\
\hline Retentate NF 300 Da & -64.61 & 0.76 & ND \\
\hline Permeate NF 300 Da & ND & ND & \\
\hline
\end{tabular}

Table 4. Secretagogue activities (gastrin/CCK-like peptides) in the PROLASTIN hydrolysate and related UF and NF fractions (ND: not determined). 


\begin{tabular}{|c|c|c|}
\hline FRACTION & $\begin{array}{c}\text { pg of CGRP-like peptides } \\
\text { per mg dry weight }\end{array}$ & ED $_{\mathbf{5 0}}, \mathbf{m g}$ dry weight \\
\hline Unfractionated hydrolysate & 4 & 19 \\
\hline Retentate UF 4 Kd & ND* & ND $^{*}$ \\
\hline Permeate UF 4 Kd & 42 & 3.6 \\
\hline Retentate NF 300 Da & 21.5 & 6.1 \\
\hline Permeate NF 300 Da & 26.6 & 6.9 \\
\hline
\end{tabular}

Table 5. CGRP-like peptides in the PROLASTIN hydrolysate and related UF and NF fractions (*ND: not detectable as the slope was very different from the CGRP standard slope).

\begin{tabular}{|c|c|c|}
\hline FRACTION & $\begin{array}{c}\text { Radical scavenging activity } \\
(\mathbf{D P P H} \text { test }) \\
\mathbf{A C}_{\mathbf{5 0}}\left(\mathbf{m g . \mathbf { m L } ^ { \mathbf { 1 } }}\right)\end{array}$ & $\begin{array}{c}\text { Antioxidant activity } \\
(\boldsymbol{\beta} \text {-carotene test }) \\
\mathbf{A C}_{\mathbf{5 0}}\left(\mathbf{m g . m L}^{\mathbf{- 1}}\right)\end{array}$ \\
\hline Unfractionated hydrolysate & 24.7 & 0.12 \\
\hline Retentate UF 4 Kd & 39.3 & 0.24 \\
\hline Permeate UF 4 Kd & 40 & 0.36 \\
\hline Retentate NF 300 Da & 32.7 & 0.24 \\
\hline Permeate NF 300 Da & ND & $<0.12$ \\
\hline
\end{tabular}

Table 6. Radical scavenging and antioxidant activities of the PROLASTIN hydrolysate and related UF and NF fractions. $\mathrm{AC}_{50}$ corresponds to the concentration of hydrolysate (mg. $\mathrm{mL}^{-1}$ protein) able to scavenge $50 \%$ of $\mathrm{DPPH}^{\bullet}$ radical or induce $50 \%$ of antioxidant activity. 


\begin{tabular}{|c|c|c|}
\hline FRACTION & $\begin{array}{c}\text { ACE-1 IC } \\
\left(\boldsymbol{\mu g} \cdot \mathbf{~ m L}^{-\mathbf{1}}\right)\end{array}$ & $\begin{array}{c}\text { ACE-1 } \\
\text { max inhibition (\%) }\end{array}$ \\
\hline $\begin{array}{c}\text { Captopril } \\
\text { (control ACE-1 inhibitor) }\end{array}$ & $4.3410^{-3}$ & 100 \\
\hline Unfractionated hydrolysate & 63 & 67 \\
\hline Permeate UF 4 Kd & 62 & 60 \\
\hline Retentate UF 4 Kd & 63 & 64 \\
\hline Permeate NF 300 Da & 52 & 65 \\
\hline Retentate NF 300 Da & 55 & 62 \\
\hline
\end{tabular}

Table 7. ACE-1 inhibitory activity of the PROLASTIN hydrolysate and related UF and NF fractions.* Captopril $21.7 .10^{-3} \mu \mathrm{g} \cdot \mathrm{mL}^{-1}(100 \mathrm{nM})$ was used as a reference inducing $100 \%$ ACE-1 inhibition. 